\title{
Evaluation of vitamin D status in children with refractory epilepsy
}

\section{Çocukluk çağı dirençli epilepsi olgularında D vitamini düzeyinin değerlendirilmesi}

\author{
Pakize KARAOĞLU, Ayşe İpek POLAT, Müge AYANOĞLU, Uluç YIŞ, Semra HIZ \\ Dokuz Eylül Üniversitesi Tıp Fakültesi, Çocuk Nöroloji Bilim Dalı, İzmir
}

\begin{abstract}
Objective: Vitamin D deficiency has been reported in children using antiepileptic drugs. Multiple antiepileptic drugs may conceivably increase the risk of vitamin D deficiency. The aim of this study is to determine vitamin $\mathrm{D}$ status and risk factors for vitamin $\mathrm{D}$ deficiency in children with refractory epilepsy.

Methods: Forty children with refractory epilepsy evaluated in our tertiary pediatric neurology outpatient clinic were included in the study, and serum 25-hydroxy vitamin D, parathyroid hormone, calcium, phosphate and alkaline phosphatase levels were assessedd. Vitamin D deficiency was defined as 25 -hydroxy vitamin D levels $<20 \mathrm{ng} / \mathrm{mL}$, and insufficiency between 21 and $29 \mathrm{ng} / \mathrm{mL}$. Correlations between vitamin D levels and type of epilepsy (generalized or localized), etiology of epilepsy (symptomatic vs idiopathic), body mass index, frequency of seizures, number, and type (old or new; enzyme inducing or not) of antiepileptic drugs, presence of intellectual disability, ambulatory status and gross motor function classification scores were evaluated.

Results: The study group consisted of 17 boys and 23 girls with a mean age of $6.65 \pm 5.29$ years. Vitamin D deficiency was identified in $25(62.5 \%)$ and insufficiency in $6(15 \%)$ the patients. There was no correlation between vitamin D levels and type of epilepsy, etiology of epilepsy, body mass index, seizure frequency, number of antiepileptic drugs, type of antiepileptic drugs, presence of intellectual disability, ambulatory status and gross motor function classification scores.

Conclusion: We found that vitamin D deficiency was increased in this cohort of children with refractory epilepsy. Vitamin D level should be monitored in patients with refractory epilepsy irrespective of the potential risk factors.
\end{abstract}

Key words: Children, refractory epilepsy, vitamin D

\section{ÖZET}

Amaç: Antiepileptik ilaç kullanan çocuklarda D vitamini eksikliği görülebileceği bildirilmiştir. Çoklu antiepileptik ilaç kullanımının D vitamini eksikliği riskini arttırabileceği düşünülmektedir. Bu çalışmanın amacı dirençli epilepsisi olan olgularda $\mathrm{D}$ vitamini düzeyinin ve $D$ vitamini eksikliği ile ilişkili olabilecek risk faktörlerinin belirlenmesidir.

Yöntemler: Çocuk nöroloji polikliniğinde dirençli epilepsi olarak değerlendirilen $40 \mathrm{olgu}$ çalışmaya dâhil edildi. Hastaların 25-OH D vitamini, kalsiyum, fosfor, alkalen fosfataz ve paratiroid hormon düzeyleri değerlendirildi. D vitamini eksikliği $25-\mathrm{OH}$ D vitamin düzeyinin $<20 \mathrm{ng} / \mathrm{mL}$; D vitamin yetmezliği $25-\mathrm{OH} D$ vitamin düzeyini 21 ve $29 \mathrm{ng} / \mathrm{mL}$ arasında olması olarak tanımlandı. D vitamin düzeyi ile birlikte epilepsi tipi, epilepsi etiyolojisi, vücut kitle indeksi, nöbet sıklığı, antiepileptik ilaç sayısı, antiepileptik ilaçların türü, eşlik eden mental retardasyon, ambulatuvar durum ve kaba motor fonksiyon klasifikasyon skorları değerlendirildi.

Bulgular: Olguların 17'si erkek, 23 'ü kızdı. Ortalama yaş: $6,65 \pm 5,29$ idi. D vitamini eksikliği 25 olguda $(\% 62,5)$ ve D vitamini yetmezliği 6 olguda (\%15) saptandı. D vitamin düzeyi ile epilepsinin tipi ve etiyolojisi, vücut kitle indeksi, nöbet sıklığı, antiepileptik ilaçların türü, eşlik eden mental retardasyon, ambulatuvar durum ve kaba motor fonksiyon klasifikasyon skoru arasında anlamlı ilişki saptanmadı.

Sonuç: Dirençli epilepsili olguların değerlendirildiği çalışmamızda D vitamini eksikliği ve yetmezliği yüksek oranda saptanmış olup, tüm dirençli epilepsili hastalarında risk faktörlerinden bağımsız D vitamini düzeyi kontrol edilmelidir.

Anahtar kelimeler: Çocukluk çağı, dirençli epilepsi, D vitamini

Alındığı tarih: 17.07.2014

Kabul tarihi: 21.10 .2014

Yazışma adresi: Uzm. Dr. Pakize Karaoğlu, Dokuz Eylül Üniversitesi Tıp Fakültesi, Nevvar Salih İşgören Çocuk Hastanesi, Çocuk Nöroloji Bilim Dalı, İnciraltı-35340-İzmir e-mail: pakizekaraoglu@gmail.com 


\section{INTRODUCTION}

The association between vitamin $\mathrm{D}$, antiepileptic drugs (AEDs) and poor bone health in epileptic patients is known ${ }^{(1-3)}$. In children this issue is particularly important because they use AEDs during the time of maximum bone mineralization ${ }^{(4)}$. Seizures, neuromotor dysfunction, long term treatment with medications affect bone health of epileptic children and vitamin D deficiency creates additional risk for poor bone health ${ }^{(5)}$. Vitamin D is also essential for organ systems other than skeletal system and deficiency has been associated with an increased risk of infections, autoimmune diseases, diabetes, metabolic syndrome, obesity, asthma and certain neurological diseases ${ }^{(6)}$.

Studies about bone mineral density and/or bone biochemistry in children treated with AEDs have found a prevalence of $25-\mathrm{OH}$ vitamin D levels less than 20 of between $25 \%$ and $75 \%{ }^{(4)}$. AEDs increase the catabolism of vitamin $\mathrm{D}$ via the induction of cytochrome P450 system ${ }^{(7)}$. Non-enzyme inducing AEDs (e.g., valproic acid) have also been associated with poor bone health ${ }^{(8)}$. Polypharmacotherapy in epileptic patients is a risk factor for vitamin D deficiency ${ }^{(9)}$. In addition to polypharmacotherapy, children with refractory epilepsy might have additional risk factors like cognitive impairment and psychiatric disturbances due to frequent seizures, motor dysfunction related immobility and frequent respiratory infections in which vitamin D may be beneficial ${ }^{(9)}$. In this study we aimed to determinate the vitamin D status and risk factors for vitamin D deficiency in children with refractory epilepsy.

\section{MATERIAL and METHODS}

In this cross sectional study, we collected data from March 2013 to June 2013, in Dokuz Eylül University Pediatric Neurology outpatient clinic in Izmir, Turkey. Children with refractory epilepsy were included in study. Refractory epilepsy was defined as at least one seizure in a month in the past six months despite treatment with at least two AEDs. Data obtained included the following: (1) demographic data (2) features of epilepsy (generalised or partial, symptomatic or idiopathic, duration of epilepsy) (3) seizure types and frequency (4) AEDs (number of AEDs, type of medication used, using enzyme inducing AEDs or not, using old or new group AEDs) (5) ambulatory or nonambulatory (6) intellectual disability (7) body mass index (8) gross motor function classification system (GMFCS) scores. Patients were not taking any multivitamin or vitamin D supplementation during the course of the study. Bone health blood tests were performed during spring of 2013 . Serum 25-hydroxy vitamin D (25-OHD), parathyroid hormone $(\mathrm{PTH})$, calcium $(\mathrm{Ca})$, phosphate $(\mathrm{P})$ and alkaline phosphatase (ALP) were measured. Vitamin D deficiency was defined as 25-hydroxy vitamin D levels $<20 \mathrm{ng} / \mathrm{mL}$, and insufficiency between 21 and $29 \mathrm{ng} / \mathrm{mL}$. AEDs were classified as new (lamotrigine, levetiracetam, oxcarbazepine, topiramate, vigabatrin, and zonisamide) or old (carbamazepine, clonazepam, ethosuximide, phenobarbital, phenytoin and valproate). Carbamazepine, phenobarbital, and phenytoin were enzyme-inducing AEDs and the others were not. Patients were classified as taking old or enzyme-inducing AEDs if at least one of their medications were belonged to these categories. The study was approved by the ethics committee, and patients and parents gave written informed consent to participate in the study. SPSS, version 15 (SPSS Inc, Chicago, IL), was used for statistical analysis. Mean 25-OHD concentration was defined (Mean \pm SD). Potential differences in study population characteristics and risk factors about vitamin D status were performed by chi-square test. P-value less than 0.05 was considered statistically significant.

\section{RESULTS}

The study consisted of 40 children (17 boys and 23 girls; mean age of $6.65 \pm 5.29$ years) with refractory epilepsy. Patient characteristics are presented in Table 1. Mean 25-hydroxy vitamin D level of the 
population was $20.68 \pm 16.09$. Vitamin D deficiency was identified in $25(62.5 \%)$ and insufficiency in 6 $(15 \%)$ of the patients. Among patients with vitamin D deficiency, only two had high PTH levels with hypocalcemia and hypophosphatemia. There was no correlation between 25-OH vitamin D levels and epilepsy type (generalized or localization related), epilepsy etiology (symptomatic vs idiopathic), body mass index, seizure frequency, number of AEDs, type of AEDs (old or new; enzyme inducing or not), presence of intellectual disability, ambulatory status, GMFCS scores (all P>0.05).

\section{DISCUSSION}

In our study vitamin $\mathrm{D}$ deficiency was identified in $25(62.5 \%)$ and insufficiency in $6(15 \%)$ of the patients. A study from Turkey reported vitamin D deficiency in $8 \%$ and vitamin D insufficiency in $25.5 \%$ of 849 healthy children and adolescents ${ }^{(10)}$. Another study with 440 healthy children showed that $40 \%$ of the subjects had 25 hydroxy vitamin D less than $20 \mathrm{ng} / \mathrm{mL}^{(11)}$. Our study showed lower levels of vitamin $\mathrm{D}$ in epileptic patients on polytherapy then these studies with healthy subjects. We did not compare the levels of our patients with healthy controls and this is a limitation of our study. But the prevalence in our patients is comparable to the reported data. Our patients live in mediterranean climate, which may place them at lower risk for vitamin D insufficiency than the general population.

Our findings are consistent with other studies reporting that epileptic children on polytherapy frequently have vitamin D deficiency ${ }^{(12)}$. It has been reported that patients under polytherapy have significantly lower 25-OHD levels than patients with monotherapy ${ }^{(9)}$.

One study reported vitamin D deficiency in 12 of 13 children with pharmacoresistant epilepsy ${ }^{(13)}$. Another study revealed vitamin D insufficiency in $51 \%$ of children with intractable epilepsy ${ }^{(14)}$. The authors found higher levels of 25-OHD in patients with adequate vitamin D intake. They also showed negative association between number of AEDs and 25-OHD levels and no association between vitamin D status and age, gender, ambulatory status, cerebral palsy, and mental retardation ${ }^{(14)}$. In this study vitamin D status was not correlated with type of epilepsy, etiology of epilepsy, body mass index, seizure fre-

Tablo 1. Patient Characteristics.

\begin{tabular}{|c|c|}
\hline Sample size & $n=40$ \\
\hline \multicolumn{2}{|l|}{ Sex (number, \%) } \\
\hline Female & $23(57.5)$ \\
\hline Male & $17(42.5)$ \\
\hline Mean age, $\mathrm{yr}, \pm \mathrm{SD}$ & $6.65 \pm 5.29$ \\
\hline Mean duration of epilepsy, $\mathrm{yr}, \pm \mathrm{SD}$ & $4.50 \pm 4.23$ \\
\hline \multicolumn{2}{|l|}{ Seizure type (number, \%) } \\
\hline Generalized & $32(80)$ \\
\hline Partial & $8(20)$ \\
\hline \multicolumn{2}{|l|}{ Etiology (number, \%) } \\
\hline Idiopathic & $15(37.5)$ \\
\hline Symptomatic & $25(67.5)$ \\
\hline \multicolumn{2}{|l|}{ Seizure types (number, \%) } \\
\hline Generalized (tonic, clonic or tonic clonic) & $25(62.5)$ \\
\hline Partial & $5(12.5)$ \\
\hline Complex partial & $5(12.5)$ \\
\hline Myoclonic & $3(7.5)$ \\
\hline Spasms & $1(2.5)$ \\
\hline Atonic & $1(2.5)$ \\
\hline \multicolumn{2}{|l|}{ Seizure frequency (number, \%) } \\
\hline Daily seizures & $23(57.5)$ \\
\hline Less than daily seizures & $17(42.5)$ \\
\hline \multicolumn{2}{|l|}{ Number of antiepileptic drug (number, \%) } \\
\hline 2 & $21(52.5)$ \\
\hline 3 & $15(37.5)$ \\
\hline 4 & $4(10)$ \\
\hline \multicolumn{2}{|l|}{ Type of AEDs (enzyme inducing or not; number, \%) } \\
\hline Enzyme inducing drugs & $11(27.5)$ \\
\hline Not enzyme inducing drugs & $29(72.5)$ \\
\hline \multicolumn{2}{|l|}{ Type of AEDs (old, new or both; number, \%) } \\
\hline Old & $3(7.5)$ \\
\hline New & $5(12.5)$ \\
\hline Both & $32(80)$ \\
\hline \multicolumn{2}{|l|}{ Intellectual disability (number, \%) } \\
\hline Yes & $31(77.5)$ \\
\hline No & $9(22.5)$ \\
\hline \multicolumn{2}{|l|}{ Ambulatory status (number, \%) } \\
\hline Ambulatory & $24(60)$ \\
\hline Nonambulatory & $16(40)$ \\
\hline \multicolumn{2}{|l|}{ Body mass index (number, \%) } \\
\hline Underweight $\left(\mathrm{BMI}<5^{\text {th }}\right.$ percentile $)$ & $6(15)$ \\
\hline Normal & $30(75)$ \\
\hline Obese (BMI $\geq 95$ th percentile & $4(10)$ \\
\hline \multicolumn{2}{|l|}{ Gross Motor Function Scale (GMFCS) scores (number, \%) } \\
\hline $1-2$ & $24(60)$ \\
\hline$\geq 3$ (need an assistive mobility device) & $16(40)$ \\
\hline \multicolumn{2}{|l|}{ Vitamin D status (number, \%) } \\
\hline Normal & $9(22.5)$ \\
\hline Deficient $(<20 \mathrm{ng} / \mathrm{mL})$ & $25(62.5)$ \\
\hline Insufficient $(20-29 \mathrm{ng} / \mathrm{mL})$ & $6(15)$ \\
\hline
\end{tabular}


quency, number of antiepileptic drugs, type of antiepileptic drugs, presence of intellectual disability, ambulatory status and gross motor function classification scores. Many potential risk factors such seizures, comorbid neuromotor dysfunction, and longterm treatment with medications may cause vitamin $\mathrm{D}$ deficiency in this population. This is a relatively small study, so that we could not find a potential risk factor contributing to low vitamin D levels.

In our study we could not find a correlation between bone markers and 25-OHD levels. Among patients with vitamin D deficiency only two had high PTH levels with hypocalcemia and hypophosphatemia. It is not exactly known whether low 25OHD levels are associated with an increased bone turnover in children using AEDs or not ${ }^{(15)}$.

Children with intractable epilepsy might need recurrent hospitalizations because of frequent infections related with their motor dysfunction and immobility. Vitamin D levels in children with refractory epilepsy might be particularly important because of its regulatory effects on immune functions ${ }^{(6)}$. There is also data about seizure control with vitamin D supplementation in children with refractory epilepsy (13). The mechanism of this action is not exactly known but thought to be due to the changes in gene expression via vitamin D receptor ${ }^{(13)}$.

\section{CONCLUSION}

In conclusion, we found that vitamin D deficiency was high in this cohort of epileptic children using polytherapy. A study with control group and a larger sample size is necessary to further validate this observation.

\section{REFERENCES}

1. Kumar J, Muntner P, Kaskel FJ, Hailpern SM, Melamed ML. Prevalence and associations of 25-hydroxyvitamin D deficiency in US children: NHANES 2001-2004. Pediatrics 2009; 124:e362-370.

http://dx.doi.org/10.1542/peds.2009-0051
2. Tekgul H, Dizdarer G, Demir N, Ozturk C, Tutuncuoglu S. Antiepileptic drug-induced osteopenia in ambulatory epileptic children receiving a standard vitamin D3 supplement. $J$ Pediatr Endocrinol Metab 2005;18(6):585-588. http://dx.doi.org/10.1515/JPEM.2005.18.6.585

3. Tekgul H, Serdaroglu G, Huseyinov A, Gökben S. Bone mineral status in pediatric outpatients on antiepileptic drug monotherapy. J Child Neurol 2006;21(5):411-414.

4. Harijan P, Khan A, Hussain N. Vitamin D deficiency in children with epilepsy: Do we need to detect and treat it? $J$ Pediatr Neurosci 2013;8:5-10. http://dx.doi.org/10.4103/1817-1745.111413

5. Shellhaas RA, Barks AK, Joshi SM. Prevalence and risk factors for vitamin D insufficiency among children with epilepsy. Pediatr Neurol 2010;42:422-426. http://dx.doi.org/10.1016/j.pediatrneurol.2010.03.004

6. Masvidal Aliberch RM, Ortigosa Gómez S, Baraza Mendoza MC, Garcia-Algar O.Vitamin D: pathophysiology and clinical applicability in paediatrics. An Pediatr (Barc) 2012;77:279. e1-279.e10.

7. Zhou C, Assem M, Tay JC, Watkins PB, Blumberg B, Schuetz EG, Thummel KE. Steroid and xenobiotic receptor and vitamin D receptor crosstalk mediates CYP24 expression and drug-induced osteomalacia. J Clin Invest 2006;116:17031712 . http://dx.doi.org/10.1172/JCI27793

8. Guo C-Y, Ronene GM, Atkinson SA. Long-term valproate and lamotrigine treatment may be a marker for reduced growth and bone mass in children with epilepsy. Epilepsia 2001;42:1141-1147. http://dx.doi.org/10.1046/j.1528-1157.2001.416800.x

9. Nettekoven S, Ströhle A, Trunz B, Wolters M, Hoffmann S, Horn R, Steinert M, Brabant G, Lichtinghagen R, Welkoborsky HJ, Tuxhorn I, Hahn A. Effects of antiepileptic drug therapy on vitamin D status and biochemical markers of bone turnover in children with epilepsy. Eur J Pediatr 2008;167:13691377. http://dx.doi.org/10.1007/s00431-008-0672-7

10. Akman AO, Tumer L, Hasanoglu A, Ilhan M, Caycı B. Frequency of vitamin D insufficiency in healthy children between 1 and 16 years of age in Turkey. Pediatr Int 2011;53:968-973. http://dx.doi.org/10.1111/j.1442-200X.2011.03486.x

11. Andıran N, Çelik N, Akça H, Doğan G. Vitamin D deficiency in children and adolescents. J Clin Res Pediatr Endocrinol 2012;4:25-29. http://dx.doi.org/10.4274/jcrpe.574

12. Fong CY, Riney CJ. Vitamin D Deficiency Among Children With Epilepsy in South Queensland. J Child Neurol 2013.

13. Holló A, Clemens Z, Kamondi A, Lakatos P, Szűcs A. Correction of vitamin D deficiency improves seizure control in epilepsy: a pilot study. Epilepsy Behav 2012;24:131-133. http://dx.doi.org/10.1016/j.yebeh.2012.03.011

14. Bergqvist AG, Schall JI, Stallings VA. Vitamin D status in children with intractable epilepsy, and impact of the ketogenic diet. Epilepsia 2007;48:66-71. http://dx.doi.org/10.1111/j.1528-1167.2006.00803.x

15. Valsamis HA, Arora SK, Labban B, McFarlane SI. Antiepileptic drugs and bone metabolism. Nutr Metab (Lond) 2006;3:36.

http://dx.doi.org/10.1186/1743-7075-3-36 